\title{
Radical Innovation for Sustainability: The Power of Strategy and Open Innovation
}

\author{
Steve Kennedy, Gail Whiteman, Jan van den Ende
}

Sustainability oriented innovation continues to garner increasing attention as the answer to how firms may improve environmental and/ or social performance while simultaneously finding competitive advantage. Radically innovating new products and services to replace harmful market incumbents is central to this thesis, yet studies to date have found it to be a highly expensive process with high degrees of uncertainty and risk. Extant research however has largely neglected to examine the details of the actual product innovation process itself and has under appreciated the influence of corporate strategic context. Our paper addresses this gap in the literature through an in-depth case study of a sustainability oriented innovation process for a radical new product within a multinational life sciences company, DSM. Our findings identify five critical organizational practices through which strategic direction has enabled the innovation process: technology super-scouting throughout the value chain, search heuristics that favor radical sustainability solutions, integration of sustainability performance metrics in product development, championing the value chain to build demand for radical sustainability oriented product innovation, and harnessing the benefits of open innovation.

() 2016 Elsevier Ltd. All rights reserved.

\section{Introduction}

"We feel the world needs something else than oil based, fossil-based resources and we also feel we should limit our impact on the environment in terms of greenhouse gas emissions" (Interviewee M)

Corporate sustainability has continuously risen on the business agenda as companies have sought to address the environmental and social problems to which they are intrinsically entangled (Bansal and Hoffman, 2012; Hart and Milstein, 2003; Whiteman et al., 2013). While sustainability was traditionally seen as a cost of doing business (Porter and van der Linde, 1995), sustainability oriented innovation (SOI) positions this as a business driver that can simultaneously improve performance and offer a source of competitive advantage (Hall and Wagner, 2012; Hart and Milstein, 2003). Many companies have embraced incremental innovations in the form of 'end-of-pipe' technical additions or 'eco-efficient' optimization of current organizational processes (Adams et al., 2015; Carrillo-Hermosilla et al., 2010). While successful in helping firms avoid unnecessary waste and costs, such innovations alone fail to address the root causes of global problems (Hart and Milstein, 2003; Whiteman et al., 2013). Encouragingly, some corporate frontrunners, alongside sustainability driven start-ups (Hockerts and Wüstenhagen, 2010), have called for the integration of radical product innovation for sustainability at the core of business strategies (Dangelico et al., 2013; Hart and Milstein, 2003). Yet radical product SOI remains understudied (Hansen and GroßeDunker, 2013) with scholars often failing to differentiate between radical and incremental forms of innovation (Dangelico, 2015).

SOIs are defined as "realized ideas that improve environmental and/or social performance compared with the current situation" (Arnold and Hockerts, 2011, 394). SOI concerns the efficient use of resource inputs, the creation of improved products and services, and the formation of new business models: all of which are aligned to traditional business principles (Nidumolu et al., 2009). Debates of whether or not it pays to be 'green' (Wu and Pagell, 2011) are now fast being replaced by the question of how to most effectively innovate to maximize the value of meeting sustainability demands (Wagner, 2007). Contemporary management literature gives preliminary insights to these new discussions (see Adams et al., 2015; Klewitz and Hansen, 2014, for systematic literature reviews), including an initial understanding of specific factors for SOI success (Dangelico, 2015; De Medeiros et al., 2014; Driessen et al., 2013). 
As the need for radical SOI becomes increasingly apparent (Tukker and Butter, 2007), companies require insight into the mechanisms that may enhance their radical innovation activities for new sustainable products. Important differentiators of SOI are the degree of novelty and the scope of intended environmental and/or social performance improvement. Research suggests that innovations seeking radical improvements in sustainability performance have a number of outstanding issues such as high complexity, uncertainty and insufficient financial returns (Geels et al., 2008; Hall and Wagner, 2012) making them less attractive for investment. What is missing is a coherent picture of the practices within the radical innovation process for sustainability, including an explicit examination of how these practices connect to corporate strategy (Arnold and Hockerts, 2011; Boons and Lüdeke-Freund, 2013).

Our paper addresses this gap and investigates a case of radical SOI for new products within one multinational firm from the life sciences industry called DSM. By inductively exploring this case, our study gives insight into how corporate sustainability strategy influences SOI through the execution of five organizational practices: (1) technology super-scouting throughout the value chain; (2) search heuristics that favor radical sustainability solutions; (3) integration of sustainability performance metrics in product development; (4) championing the value chain to build demand for radical SOI; and (5) harnessing the benefits of open innovation. We believe these insights into the specifics of the innovation processes contribute to our understanding of radical SOI, but also add to discussions of strategic influence within the traditional innovation management literature.

We begin our paper with a brief review of the literature on radical SOI and the influence of strategic context. Next, we describe the exploratory qualitative case study approach and our research procedure. We then present our case findings and a process model of radical product SOI. This is followed by discussion of the implications of our findings for research on SOI and traditional product innovation. Finally, we draw conclusions, offer limitations of the study and provide directions for future research.

\section{Radical product SOI}

Innovation has long been part of corporate strategy, recognized as a potential source of sustained growth for firms (Schumpeter, 1934) through changes in products, processes, business models and/or organizational structures (Dewar and Dutton, 1986). More recently, new product innovation has been recognized as a key way in which firms can make progress on sustainability performance while simultaneously improving marketplace competitiveness (Dangelico, 2015; Hart and Milstein, 2003; Nidumolu et al., 2009).

SOI for new products seeks to achieve market differentiation, but also a relative improvement in environmental and/or social performance compared to the current situation (which in itself may be a market differentiator). What exactly constitutes SOI for new products has been a matter of much debate in management research, and there remains a range of definitions and terminology such as 'green product innovation', 'eco-innovation' and 'sustainability-driven innovation' (see Carrillo-Hermosilla et al., 2010). We adopt the term product SOI as it implies a process deliberately seeking outcomes to improve current environmental and/or social performance (Hansen and Große-Dunker, 2013). The term directs firms to consider both environmental and social dimensions in the innovation process, but does not dictate that a performance improvement of both is necessary for every innovation; i.e. a portfolio of environmentally and socially focused innovations may be more effective to improve overall sustainability performance of a firm.

Characterizations of product SOI commonly use two dimensions. The first is an assessment of novelty, relying on the radical and incremental distinction used in conventional innovation research. Incremental innovations are understood as competence-enhancing, small adaptations made on a continuous basis (Carrillo-Hermosilla et al., 2010), while radical innovations are episodic, 'frame bending' (Plowman et al., 2007) and often replace existing parts or entire systems (CarrilloHermosilla et al., 2010). A second dimension is a consideration of the extent to which product innovation improves sustainability performance, or its 'greenness' in ecological terms (Driessen et al., 2013). Innovations seeking radical sustainability improvements to systems will likely require different practices within the innovation process than those aiming for marginal improvements to existing ones (Adams et al., 2015; Hall, 2002). This paper refers to radical product SOI as innovations that are high in novelty and also aim for significantly improved sustainability performance of systems.

\section{Understanding the process of radical product SOI}

Innovation research has shown radical product innovation as a particularly difficult process as it requires fundamental changes to existing practice (Dewar and Dutton, 1986; Sandberg and Aarikka-Stenroos, 2014), including a departure from the present knowledge base and/or market relations (Bower and Christensen, 1995; Humble and Jones, 1989). By nature, radical innovation involves greater uncertainty than its incremental counterpart and is more likely to be discontinued due to the greater time needed in development and demands for high investment return over short time frames (Green and Welsh, 2003). Furthermore, incumbent companies are less likely to initiate processes for radical innovations as they may prefer less disruptive innovation that seeks to leverage current competencies (Bower and Christensen, 1995; Hall and Vredenburg, 2003; Hockerts and Wüstenhagen, 2010).

\footnotetext{
1 We acknowledge that in certain circumstances, radical improvements in sustainability performance may be possible through either: (1) innovations with low novelty; or (2) continuous incremental change leading to radical transformations (Plowman et al., 2007).
} 
Management studies have also shown that there are unique sets of issues specific to sustainability that need to be addressed throughout the product innovation process (Geels et al., 2008; Hall, 2002). For instance, innovation teams often face the added complexity of reconciling potentially opposed sustainability dimensions and stakeholder demands (Dangelico et al., 2013; Hall and Vredenburg, 2003), and must work with higher ambiguity due to either scientific uncertainty (Hall and Vredenburg, 2003) or incomplete information (Wu and Pagell, 2011). Furthermore, the commercialization of sustainable products is fraught with difficulties as companies struggle with issues such as ensuring commercial viability (Dangelico and Pujari, 2010), higher scrutiny from stakeholders (Hall, 2002) and battling lock-in mechanisms (Carrillo-Hermosilla et al., 2010). Thus, radical SOI can be an expensive process of innovation with high uncertainty and risk (Geels et al., 2008; Hall and Wagner, 2012).

Given these multiple challenges, management researchers have sought to identify the organizational capabilities and practices that account for successful radical innovation of new products (Slater et al., 2014) and those specific to SOI (Dangelico et al., 2013; Driessen et al., 2013; Hallstedt et al., 2013). De Medeiros et al. (2014) synthesize SOI success factors into four categories: (1) Market, law and legislation knowledge such as green purchasing behavior (Foster et al., 2000) and competitor monitoring; (2) Inter-functional collaboration across internal departments and with external stakeholders (Dangelico et al., 2013); (3) Innovation-oriented learning including developing SOI competencies (Hallstedt et al., 2013) and capabilities for critical reflection; and (4) R\&D Investments in SOI infrastructure, human resources and technology (Horbach et al., 2012). However, most of the existing studies are either conceptual in nature or have quantitatively measured outcomes, leaving the SOI process for new products as a 'black box' (Boons and Lüdeke-Freund, 2013).

A notable exception is the qualitative study of Keskin et al. (2013) on small sustainability driven entrepreneurial firms engaging in moderate to radical SOI. This empirical work develops a temporally differentiated model of critical internal (human resources and; managing resources) and external (external validation, network, and market orientation) practices. We do not yet know if and how this framework fits within the multinational firm context, which is likely to be more complex than the business environment of small and medium-sized enterprises (SMEs). For instance, the critical difficulties faced in the innovation process may differ as multinationals are likely to have more in-house knowledge and resources than SMEs, yet their larger size gives the potential for corporate strategy and innovation activities to become separated.

\section{Influence of strategic context on radical product SOI}

Despite the proliferation of SMEs, large multinational firms continue to dominate many value chains. How and why large firms form and implement proactive sustainability strategies has attracted much scholarly attention resulting in models categorizing stages of organizational change (see Kolk and Mauser, 2002). SOI is often described as a cornerstone of proactive sustainability strategies (Adams et al., 2015; Hart and Milstein, 2003). Studies show that large firms most often begin with incremental innovations before maturing towards radical SOI (Nidumolu et al., 2009), while others (a minority group) start with the goal of radical change, organizing semi-autonomous business units or spin-offs (Schaltegger et al., 2016). Yet the strategic mechanisms influencing the choice of innovation pathways, particularly for radical innovation, remain unclear (Boons and Lüdeke-Freund, 2013).

Similarly, the wider innovation literature has largely ignored the influence of corporate strategy on activities within the innovation process, choosing to focus on identifying how companies organize for innovation including the leveraging of organizational competencies and resources (Henard and Szymanski, 2001). Past innovation studies have shown that corporate strategy can affect the mix of radical versus incremental innovation in the firm's portfolio (Cooper et al., 2001) and that the organizational separation of innovation activities from other firm activities is a valuable mechanism to maximize strategic choices such as forming commercial spin-offs (Bower and Christensen, 1995; O'Connor and DelMartino, 2006). Furthermore, 'portfolio management', which seeks alignment of the portfolio of projects with technology, market and timing as set out by corporate strategy, is an important connecting mechanism (Cooper et al., 2001; Ilinitch and Schaltegger, 1995). In addition, the inclusion of explicit sustainability metrics to screen products at checkpoints within a linear product development model (Arnold and Hockerts, 2011; Blomquist and Sandström, 2004) can be an effective tool. While many of these studies stress the importance of innovation strategy, few examine how such strategies actually influence organizational behavior and the process of radical innovation.

In summary, the actual process of radical SOI itself (e.g. the series of practices through which the innovation is enacted) remains unclear. Only a handful of empirical studies relate corporate sustainability strategy to the practices of innovation, and many are limited in their scope: These studies tend to explain the influence of firm strategy on product SOI only through formalized mechanisms or portfolio management, and thus ignore other organizational practices and routines inherent in innovation processes.

In our paper we address these gaps in the literature by developing a process model of radical product SOI based on a qualitative case study. Our model identifies five critical internal and external organizational practices involved in radical product SOI and indicates how a proactive sustainability strategy influences how these practices are executed.

\section{Methods}

Our paper is an inductive inquiry employing a qualitative case study research strategy to investigate the on-going process of a radical product SOI within DSM, a well-known corporate frontrunner in sustainability. We identified DSM as a company 
with a bold organizational sustainability strategy, offering the opportunity to develop new and novel insights into its influence on the firm's process of radical innovation (Eisenhardt, 1989).

DSM is a global public limited company (listed on NYSE Euronext) in material and life sciences and has a long history of transformation and innovation from its origins in coal mining. The company has won numerous sustainability awards, including topping the Dow Jones Sustainability Index of its respective industry on multiple occasions, and is working toward aggressive targets for transforming both its innovation pipe-line and running business (DSM, 2011a). From the current innovation portfolio, we selected to investigate a 'new to the world' bio-based succinic acid called Biosuccinium ${ }^{\mathrm{TM}}$. This selection was made by the first author in discussion with the Chief Technology Officer based on its perceived representation as a radical sustainability oriented product innovation (Yin, 2003), its advanced stage toward full commercialization and our access for data collection.

\section{Selected radical sustainability oriented innovation}

Biosuccinium $^{\mathrm{TM}}$ is a bio-based succinic acid $\left(\mathrm{C}_{4} \mathrm{H}_{6} \mathrm{O}_{4}\right)$ that may be used as a building-block component for the production of plastics. Global production of plastics continues to rise, with 299 million tons produced in 2013 (The Worldwatch Institute, 2015). Fossil-fuel derived plastics dominate global production, yet are recognized as unsustainable due to high greenhouse gas emissions and additional ecological impacts (Chen and Patel, 2012). Succinic acid "has the potential to create a 'green' $\mathrm{C}_{4}$ platform" (Patel et al., 2006, 42) acting as a replacement of fossil-fuel derived monomers such as (fossil based) succinic acid, adipic acid, 1.4 butanediol (BDO), tetrahydrofuran (THF) and y-butyrolactone (GBL). Bio-based succinic acid is now becoming available at a commercial scale for the first time, allowing plastics to be made from bio-renewable sources.

Due to its high upstream position Biosuccinium ${ }^{\mathrm{TM}}$ potentially services approximately 80 value-chains, making the conversion to a bio-based paradigm a reality for a diverse set of users. Example end use applications include: running shoes (thermoplastic), automotive textiles (flexible foam), wood and furniture coatings and adhesives in the construction industry (DSM, 2012). Aided by a novel sustainable production process, Biosuccinium ${ }^{\mathrm{TM}}$ offers a radical improvement to sustainability performance compared to marketplace incumbents (Cok et al., 2014). For instance, the carbon footprint (kg CO2-eq/kg acid) can be reduced by $90 \%$ versus fossil-fuel derived adipic acid (DSM, 2012). This gives the potential for a highly significant positive environmental impact of Biosuccinium ${ }^{\mathrm{TM}}$ based applications - approximately $2000 \mathrm{kton}$ of $\mathrm{CO}_{2}$ reduction if the expected market development by 2020 is achieved.

Initiated by DSM, the innovation is now established in a joint venture called Reverdia formed in partnership with Roquette Freres, a family-owned French company globally high-ranked in processing plant-based raw materials. Reverdia JV is steered by DSM's Emerging Business Area (EBA) Bio-based Products and Services together with Roquette Freres. The EBA is a marketdriven innovation unit that reports directly to the DSM Innovation Centre. Biosuccinium ${ }^{\mathrm{TM}}$ is a forerunner in a portfolio of biobased products being developed within the EBA.

DSM started to operate its first commercially sized production facility in December 2012 and has since optimized product

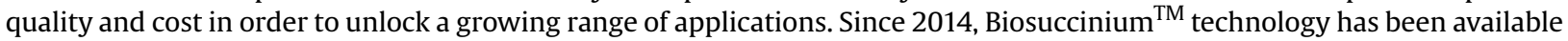
under license for firms to integrate bio-succinic acid production into their business offerings. Additional large scale commercial production plants depend on the uptake of such licensing opportunities.

\section{Research procedure}

To investigate the case, we collected data from multiple sources: qualitative interviews, documentary evidence and direct observations. This approach offered the opportunity for converging lines of inquiry and the processes of corroboration and triangulation (Yin, 2003). The CEO and the Chief Technology Officer of DSM, and the General Manager of Reverdia, all formally consented to this case study. Extensive access was granted to the first author with data collected at several locations within the Netherlands, and supplemented by informal interviews by the second author among various senior management executives. In addition, four roundtable discussions on SOI (including specific to the case) were held involving all three authors of this paper, representatives of DSM and other corporate managers working in SOI. Data were collected from March 2012 until August 2013.

Nineteen formal interviews were conducted with informed consent. Interviewees were purposefully sampled (Lincoln and Guba, 1985) beginning with two high level managers who held overview perspectives of the entire portfolio of innovation activities (Chief Technology Officer) and the EBA Bio-based Products and Services (R\&D Director), respectively. A snowball technique was then used to select interviewees that were capable of providing information on the organizational practices of the Biosuccinium $^{\mathrm{TM}}$ and the influence of the corporate sustainability strategy (Corley and Gioia, 2004). These led to further interviews with the management team (CEO Reverdia), ideation and development team (including Head Fermentation Scientist, R\&D Project Manager, Application Team Leader), commercialization team (including Business Analyst, Marketing Manager, New Business Development Manager), innovation support (including VP Open Innovation, Sustainability Assessment Team) and external academics (LCA Researcher, Bio-tech Researcher).

Interviews were conducted on a one-to-one, face-to-face basis and held at the interviewees respective places of work. Interviews ranged in length from 30 to 120 minutes and amounted to over 16 hours in total. Seventeen interviews were audio recorded with the informed consent of the interviewee and extensive notes were taken in the case of the two exceptions. A semi-structured interview design was utilized for a relaxed flow of conversation and exploration into interesting lines of 
enquiry. Interviewees were invited to 'tell the story' of the innovation process based on their perspective and experiences, with prepared probes used to enter more in-depth levels of understanding 'how' and 'why'. The interview protocol acted as a checklist (Lofland et al., 2006) with specific questions continuously adapted in accordance with the role of the interviewee and our developing understanding of the case. Interviews were broadly structured as follows: (1) past relevant personal experiences and personal role within the innovation process; (2) overview of the history and events of the innovation process; (3) perceived internal and external factors influencing the process; and (4) a closing section of reflections and the opportunity to bring to attention any issues not discussed. An example interview protocol is provided in the appendix.

Observations and documentary evidence were used to understand the context of the case study, permitting more insightful exchanges with interviewees and corroborating their responses. Internal archival documents ${ }^{2}$ included project presentations and project posters, while publically-available data included biotechnology research reports, industry publications, press releases and DSM's integrated reports. Observations were made before, during and after interviews while still located at the company. For instance, the first author occasionally joined interviewees for lunch enabling informal discussions and allowing him to observe social interactions and subtle instances of the organization's sustainability culture such as waste practices and safety on stairs. The first author also shadowed the Lead Fermentation Scientist for a day that included an accompanied tour of DSM facilities and 'passive participation' (Schwartz and Schwartz, 1955) of a project team meeting. In total, 12 unique visits were made to 4 facilities within the Netherlands across the data collection period.

\section{Data analysis}

Data analysis proceeded alongside data collection as an iterative process that enabled amendments to interview protocols and sampling new interviewees based on emerging lines of inquiry (Corley and Gioia, 2004; Eisenhardt, 1989). Analysis began with the production of contact summary sheets (Miles and Huberman, 1994) at the earliest opportunity after the closing of interviews and full transcription of all interviews. Contact summary sheets were used as on-going streams of consciousness (Eisenhardt, 1989) to record immediate reflections on interviewee responses, ideas for lines of enquiry and further data collection. In addition, contact summary sheets were used in conjunction with documentary evidence to construct a descriptive write-up and timeline of the Biosuccinium ${ }^{\mathrm{TM}}$ innovation (Yin, 2003). This description provided a familiarity with the company, market setting, and basic information pertaining to the product characteristics and production process.

Coding was conducted by the first author in two overlapping processes using the computer qualitative analysis software NVIVO. Firstly, initial coding involved a sentence by sentence examination of the interview transcripts to identify and code data incidents (Lofland et al., 2006). Initial coding retained many 'in vivo' phrases used by interviewees and resulted in a numerous and diverse set of codes. Secondly, focused coding sought for relationships in the data by comparing codes, merging when appropriate and forming categories and sub-categories of similar incidents (Corley and Gioia, 2004). These categories were then subsequently collapsed further into higher-level themes with focusing on the primary research questions at the center of our analysis (Lofland et al., 2006). Emergent themes were discussed between authors and a model of the critical organizational practices through which corporate strategy influenced the innovation process was developed. Finally, the findings of the study were validated by two key interviewees in addition to two senior managers within the company, and comparisons of our emergent model were made with the extant literature (Eisenhardt, 1989).

\section{Case findings}

Sustainability is a core value of DSM (Internal document, 2012a). The company is led by a strong CEO/Chairman with a clear and public vision that the company should help tackle the sustainability challenges facing the global society: "It's not only about growing the profits and share price... but at the same time [we] have the responsibility to improve it (the planet) in such a way that our children can continue to build on it, too. It's a kind of stewardship, which I really enjoy" (Steffen, 2011, 60). His strategic drive to contribute to solving the world's sustainability problems permeates the organization and top management team.

DSM adopts the Brundtland (UNWCED, 1987) definition of sustainability and embraces the Triple P concept of People, Planet and Profit. This general policy setting is not unusual. However, the company has made a conscious strategic choice to shift its sustainability posture from merely a responsible contributor to society, to positioning sustainability as one of its four strategic business drivers ${ }^{3}$ (DSM, 2010). Through a process conducted approximately every five years called the 'Corporate Strategy Dialogue' the company identifies the defining key global megatrends (global shifts, climate and energy, health and wellness) and determines the sustainability challenges these pose to society. Through this strategy formation process, DSM begins to search for business opportunities by conducting a detailed analysis of technology fit with the organization's capabilities and strengths, and then firm-specific analysis of competitive advantage: "Where can we win?" This analysis provides the basis for the firms' innovation activities: "We make sure that innovation leads to sustainable developments that really help us long term, so for generations to come" (Interviewee K).

\footnotetext{
${ }^{2}$ We refer to these data in our case findings as internal documents.

3 The remaining three strategic business drivers are: innovation, high growth economies, and acquisitions \& partnerships.
} 
This process of strategically selecting sustainability as a business driver was integral to the formation of the EBA Bio-based Products and Services in which the Biosuccinium ${ }^{\mathrm{TM}}$ innovation is set. Taking the assessment of sustainability challenges, such as the end of the oil age and climate change (Internal document, 2012b), and the firm's current and developing competencies, DSM identified the market opportunity of setting up a business platform to deliver innovations that "meet the growing demand for sustainable materials that deliver value for performance, have less impact on the environment, and minimize the burden on our limited natural resources" (DSM, 2011b, 3).

Our research indicates that the strategic choice for sustainability by DSM went far beyond simply affecting the start-up of the innovation unit. This strategic choice had a strong and direct effect on the organizational practices of the Biosuccinium ${ }^{\mathrm{TM}}$ innovation process. Our analysis identifies five critical organizational practices: (1) technology super-scouting throughout the value chain; (2) search heuristics that favored radical sustainability solutions; (3) integration of sustainability performance metrics in product development; (4) championing the value chain to build demand for radical SOI; and (5) harnessing the benefits of open innovation. Table 1 presents a description of the five primary mechanisms with illustrative comments. Below we will indicate why these practices were crucial for the success of Biosuccinium ${ }^{\mathrm{TM}}$ and how the sustainability strategy of DSM affected their execution.

Table 1

Illustrative comments supporting case findings

\begin{tabular}{|c|c|c|}
\hline Organizational Practice & Description of Organizational Practice & Key Representative Comments \\
\hline $\begin{array}{l}\text { Technology super-scouting } \\
\text { throughout the value chain }\end{array}$ & $\begin{array}{l}\text { Engaging with diverse value chain actors to identify } \\
\text { business opportunities of sustainability solutions. } \\
\text { Helped to identify which bio-based product to } \\
\text { develop, tested potential value propositions, and } \\
\text { built latent demand. }\end{array}$ & $\begin{array}{l}\text { "The first meetings with [Value Chain Intermediates A and } \\
\text { B] were before the sustainability drive, but just a curiosity: } \\
\text { 'Hey, new materials! This is my job!' [...] But couple that to } \\
\text { the sustainability drive, of course we really wanted to build } \\
\text { a partnership, because they were thinking about an } \\
\text { application of what we could make bio-based" (VP of Open } \\
\text { Innovation) }\end{array}$ \\
\hline $\begin{array}{l}\text { Search heuristics that favor } \\
\text { radical sustainability } \\
\text { solutions }\end{array}$ & $\begin{array}{l}\text { Organizing search to backcast from ideal economic } \\
\text { and environmental performance. Led to } \\
\text { identification of novel production route for a best- } \\
\text { in-class environmental footprint. }\end{array}$ & $\begin{array}{l}\text { "In the end it (sustainability) enabled us to do something } \\
\text { that was really breakthrough. Otherwise we would not have } \\
\text { done that. Would have probably said: 'could we make E. coli } \\
\text { maybe a bit better than others have done?' Something like } \\
\text { that" (Interviewee I) }\end{array}$ \\
\hline $\begin{array}{l}\text { Integration of sustainability } \\
\text { performance metrics in } \\
\text { product development }\end{array}$ & $\begin{array}{l}\text { Equal weighting of cost, quality and environmental } \\
\text { sustainability in product development performance } \\
\text { metrics. Ensured strategic intention of a better } \\
\text { environmental footprint than fossil-fuel derived } \\
\text { market incumbents by guiding development } \\
\text { decision-making. }\end{array}$ & $\begin{array}{l}\text { "People don't see it (sustainability) as something that it is } \\
\text { complex, an extra burden. People see it as a business driver } \\
\text { that makes a lot of sense. [...] It is not about the reduction of } \\
\text { an emission, or something like that it is about a completely } \\
\text { different way of thinking. Just forget about the past, look at } \\
\text { how we can do it now. It is more revolution, it is not } \\
\text { evolution." (Interviewee I) }\end{array}$ \\
\hline $\begin{array}{l}\text { Championing the value chain to } \\
\text { build demand for radical SOI }\end{array}$ & $\begin{array}{l}\text { Acting as value chain 'captain' to mobilize } \\
\text { downstream firms and speed up market } \\
\text { development. Leveraging company sustainability } \\
\text { reputation to access brand owners to drive market- } \\
\text { pull. }\end{array}$ & $\begin{array}{l}\text { "What is different is how it is now in our marketing } \\
\text { strategy. Because we're now trying to create this pull. Find } \\
\text { the brand owners. We would probably not have done that if } \\
\text { we were just coming with something that is cheaper. You } \\
\text { show [it to] your customer. You're done!" (Interviewee B) }\end{array}$ \\
\hline $\begin{array}{l}\text { Harnessing the benefits of open } \\
\text { innovation }\end{array}$ & $\begin{array}{l}\text { Providing a combined space for externally-oriented } \\
\text { organizational practices. Sustainability strategy } \\
\text { facilitates engagements with like-minded actors. }\end{array}$ & $\begin{array}{l}\text { "So sustainability is a door-opener. It's an important aspect } \\
\text { that helps us talk to many people, have many customers } \\
\text { willing to look at it, willing to spend time on investing it and } \\
\text { so on" (Interviewee B) }\end{array}$ \\
\hline
\end{tabular}

\section{Technology super-scouting throughout the value chain}

The first task of the newly created innovation unit was to identify a new portfolio of bio-based products to develop. Expectedly the corporate strategic choice for sustainability was very much central to this process: "I think basically at that time, once you have said 'so let's go for sustainable products' the obvious next question is: 'which products precisely?'” (Interviewee J). This process involved ranking potential new products based on estimated market size, fit with the current competencies of the firm, the perceived chance of developmental success, and ultimately a strong sales value proposition. Among the criteria, the requirement for the product to offer a clear environmental improvement was made explicit: "So it should be: much lower [cost] than what was available, it should have quality advantages over what was available, and it should have environmental advantages over what was available. And only when you would meet these three things it would be worthwhile to pursue. And that was why we selected succinic acid" (Interviewee I).

One of the interesting organizational practices within this portfolio management process was the influence of the relatively independent VP of Open Innovation, who described part of his job as acting as a 'technology super-scout' - travelling around the world to scout out new and potential uses of bio-based technology, and discuss challenges and opportunities within the value chain. This work was conducted mindful of the corporate strategy for sustainability, as the VP of Open Innovation explained: "DSM, the board and Feike (CEO)...was starting (in 2004) to mention global warming as a real threat to the world, where the chemical industry should take its responsibility." In 2004, during discussions with a number of Asian 
companies, he identified that the immediate market potential for succinic acid could be enormous ( $50 \mathrm{kton}-150 \mathrm{kton})$, if innovative technology could be developed to allow the bio-based product to be used in polybutylene succinate (PBS). A biobased PBS could then be used in applications such as polyethylene mulch film (e.g. agricultural use), polypropylene injection molding (e.g. consumer goods), polystyrene foam (e.g. packaging), fibers (e.g. textile) and synthetic paper that were not currently using bio-based inputs.

Furthermore, the super-scouting activities of the VP of Open Innovation identified which sustainability value propositions may work in the marketplace, helping to not only form the product portfolio but also inform how such products should be produced. The VP of Open Innovation explained: "I visited Nike, the headquarters....And, of course, tested the value proposition. Is it biodegradability for the shoes if we make polyurethane soles and replace certain parts or apply succinic to the glue? Or is it bio-renewability? It was bio-renewability but not biodegradability." These engagements were thus successful in giving the firm a better idea about the challenges faced by downstream companies, perceptions towards bio-based activities and value propositions, and more specifically a feeling that Biosuccinium ${ }^{\mathrm{TM}}$ specifically may be well received in the marketplace. It also helped to create latent demand within the supply chain, which was later capitalized upon.

\section{Search heuristics that favor radical sustainability solutions}

Once bio-based succinic acid was identified as an attractive option to develop, an innovation team was formed and began to assess all the ways it could theoretically be produced. This practice is described by DSM as a 'technology challenge session': "An important point at that moment was that I also did a technological challenge session within DSM to see what were the strong and weak points of the technology and what should we focus on? Which is a kind of standard thing to do because jumping on the technology may not be the best one" (Interviewee J).

While described as 'standard' practice, the technology challenge session was a critical practice for finding a radical sustainability solution. As a strategic business driver, "sustainability is a guiding principle" of the product innovation process within DSM, meaning “every step should support DSM's Sustainability mission” (Internal document, 2009, 39). This was evident in the assessment of the theoretical production process, which aimed to: "Develop the best process for fermentative succinic acid production, that is: sustainable with lowest carbon footprint" (DSM, 2012, 5). Starting from the ideal production process, economically and environmentally, the innovation team backcasted to search for an optimal production process: "But we were at that point in time looking at will this technology be good enough from an economic perspective but also from an environmental perspective" (Interviewee $\mathrm{O}$ ).

The innovation team quickly realized that more conventional production routes did not offer the best solution: "To be honest, the line of thought was at first that if you're producing $100 \mathrm{kton}$ of succinic and $100 \mathrm{kton}$ of gypsum [salt] it doesn't feel too sustainable" (Interviewee J). Instead, the team was successful in finding a novel route of production to what market competitors were developing. Concurrently, Roquette Freres (JV partner) was simultaneously pursuing the conventional production route until the novel route was proven to be effective by DSM's in-house team. This radical production process was later selected because it could potentially deliver high economic and environmental performance.

DSM's search for radical sustainability solutions eventually resulted in a production route that could produce a product with a significant best-in-class carbon footprint (Cok et al., 2014). It could also be produced at a market competitive price, while simultaneously offering 'greenfield' space in terms of intellectual property restrictions as competitors remain focused on conventional production routes. Interviewee O explained: “you would like to have a much cleaner process, a much more focused production. Less side products, etc. And by doing that, that's good for the environment and by doing that, that's also good for the economics."

Integration of sustainability performance metrics in product development

The development of the product was guided by a set of performance metrics that aimed to optimize how Biosuccinium ${ }^{\mathrm{TM}}$ would be made. Environmental sustainability, as the central strategic driver, was integrated as one of three primary metrics alongside achieving a low cost and a high quality product. High performance on these three concerns together was perceived to be critical for market success.

Firstly, achieving a high quality bio-based succinic acid was critical in order to enter markets where extremely pure 'monomers' are required by customers (Interviewee I). Secondly, while price premiums for certain applications were potentially available for short time periods before production scale is reached, it was acknowledged that these would not be available in the long term. Thus, the product needed the capability of being mass produced at a price comparable to the existing incumbents it was proposing to replace. Thirdly, a low environmental footprint was required to meet strategic sustainability aims and was integral to the sales value proposition, in particular to attract early adopters. While Biosuccinium $^{\mathrm{TM}}$ held the sustainability advantage of bio-renewability ${ }^{4}$ versus fossil-fuel derived incumbents, the development

\footnotetext{
${ }^{4}$ During the innovation process, the 'food-versus-fuel' (bio-based products) debate became more prevalent as a key environmental sustainability concern (Interviewee P). While Biosuccinium ${ }^{\mathrm{TM}}$ is currently produced from first-generation biomass it will be produced from second-generation once deemed commercially viable. Concurrent to the Biosuccinium ${ }^{\mathrm{TM}}$ project, DSM has invested heavily in a second-generation biomass project, which will facilitate the availability of such supply for its bio-based products.
} 
team sought to ensure that it would also have a better environmental footprint: “Bio-based doesn't necessarily mean sustainable" (Interviewee M).

Critically, finding ways to minimize the product's environmental footprint was not considered an extra difficulty by the development team (Interviewee I). On the contrary, it was considered key to achieving a low cost production process and ultimately the commercialization of the product. To this end, the development team pioneered the use of life cycle assessments (LCA) within DSM (Interviewee L), using it to proactively guide choices and validate decisions. Interviewee F explained how environmental data affected product development decisions: "they really used the LCA to say 'Okay, are we going to choose this process or that process'. And they say 'okay which one is better in terms of environmental point of view.'” Furthermore, it was acknowledged that LCAs would also be necessary to validate green credentials to customers. For this work, the development team decided to engage with a university as an independent third-party. This not only offered the team assurances that their LCA calculations were accurate, but also provided greater external credibility to results in the marketplace (Interviewee P).

\section{Championing the value chain to build demand for radical product SOI}

To successfully commercialize Biosuccinium ${ }^{\mathrm{TM}}$, DSM's direct customers, which serve a wide variety of value chains and potential applications, need to switch from using a fossil-fuel derived market incumbent. This transformation will only occur if there is perceived support further downstream in value chains by intermediates and end-users. In recognition of this situation, DSM seeks to be the value chain enabler or 'captain' (Interviewee G).

This practice of commercialization involves market-push activities such as offering free samples and reporting the sustainability benefits, but also encompasses organizing the market-pull from intermediates and downstream companies: "Working across the value chain with (ag)-feedstock players, (petroleum based) incumbents and/or downstream users" (Internal document, 2012b, 27). Through this practice, DSM helps to speed up the development of the market and 'wins time' (Interviewee $\mathrm{G}$ ), by fast tracking the introduction and adoption of Biosuccinium ${ }^{\mathrm{TM}}$ (and the upcoming bio-based product portfolio) in the marketplace. This activity began early in the innovation process with the super-scouting work by the VP of Innovation, and was later continued by a commercialization team formed once the product was under development.

A proactive sustainability strategy, and its significance within the product innovation process, supports DSM's value chain captaining approach. Actors throughout a multitude of value chains, and in particular brand owners, were keen to discuss Biosuccinium $^{\mathrm{TM}}$ when approached with a potential sustainability solution. Interviewee J explained the brand owners' interest in sustainability and the resulting market-pull: "But people know Adidas, Nike, Puma, those are companies who want to distinguish themselves from their competition based on sustainability....Because Nike and Adidas don't make shoe soles themselves. They buy that stuff. So they have to ask for more sustainable products (from their suppliers)."

Located at the start of value chains, life science companies like DSM may rarely directly engage with brand owners unless

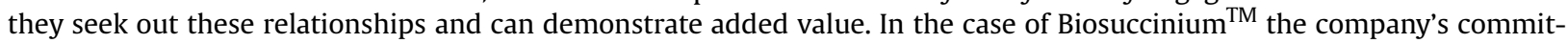
ment to radical SOI was an effective door-opener, providing opportunities to create market-pull: "So big companies, TPU (Thermoplastic polyurethane) producers invited me to go talk to Nike, to go talk to Adidas, to Puma and so on... And that is only, coming back to sustainability, the reason that we can do that at this point is only the sustainability" (Interviewee B). Without a strong reputation in both radical innovation and sustainability, interviewees doubted if these engagements would have been possible: "Sometimes you don't even get in right, you have a new product and they say that we are not really interested. But if you are a Dow Jones Sustainability leader it can help you to have that discussion" (Interviewee K).

\section{Harnessing the benefits of open innovation}

Open innovation is the endorsed innovation approach of DSM, which the company states is simply a competitive necessity (Internal document, 2009). Open innovation was fundamental to the Biosuccinium ${ }^{\mathrm{TM}}$ innovation and the ability of the company to develop a timely, sustainable and commercially viable product. Examples of open innovation can be identified throughout the SOI process from initial idea generation through to the commercialization activities at, and beyond, its launch. Significantly, this collaborative approach enabled the innovation team to harness the opportunities offered by adopting a sustainability strategy.

From the outset of the SOI and throughout its commercialization, open innovation empowered the company in its desire to act as a sustainability solutions provider. Open innovation in the early super-scouting activities helped find the value chain actors interested in sustainability issues, whereby the company's strategy could act as a door-opener and the product could receive attention. The VP of Open Innovation notes the complementary nature of the sustainability strategy and open innovation: "Yeah, I was already preaching open innovation when I talked to Nike, because we were invited because of the sustainability issue. Can you please help us? So they were applying open innovation too. They wanted to have sustainable materials." These engagements not only allowed for early feedback on potential products, potential sustainability value propositions, but also the identification of unexpected demand: "When we approached these people making running shoes, etc. We knew that they were using a lot of adipic acid, but never thought that they would consider to replace adipic acid by succinic acid in their materials simply because it had all these advantages I was mentioning. But actually Nike and others they showed a high interest to consider that. So that was kind of an extra market outlet never thought about when we were kind of selecting the targets" (Interviewee I). 
Open innovation was also strongly applied in the concept design and development phases, enabling DSM to take advantage of how the sustainability strategy could help to form new partnerships. For instance, industry experts interested in new bio-based products engaged in a discussion session concerning the technology of the production route, and external institutions were eager to partner to assess the environmental footprint of production route choices. Most significantly, DSM was able to partner with Roquette Freres, another strong multinational company, and form a partnership based on mutual belief in a bio-based economy and shared sustainability strategy (Interviewee J). This partnership brought many benefits such as access to quantity of raw material quality and quantity of raw material, instilling market confidence and most critically speeding up the time to market entry.

\section{Discussion and implications}

\section{A process model of radical product SOI}

Extant literature has shown radical product SOI to be a difficult process with high degrees of uncertainty and risk (Hall and Wagner, 2012). Management scholars have sought to help managers by identifying organizational capabilities and practices for success (De Medeiros et al., 2014; Slater et al., 2014). Yet these studies commonly fail to distinguish between incremental and radical innovation (Dangelico, 2015), and moreover treat the innovation process as a 'black box' by quantitatively measuring outcomes (Boons and Lüdeke-Freund, 2013). Our case findings contribute to an important gap in the literature by offering empirical findings on the process and practices used by a large multinational firm to achieve radical product SOI.

Figure 1 illustrates the innovation process of a radical product SOI based upon our empirical findings. Our conceptual model depicts the temporal phases of the radical innovation process and identifies five critical organizational practices through which DSM's strategic direction enabled the innovation process of Biosuccinium ${ }^{\mathrm{TM}}$.

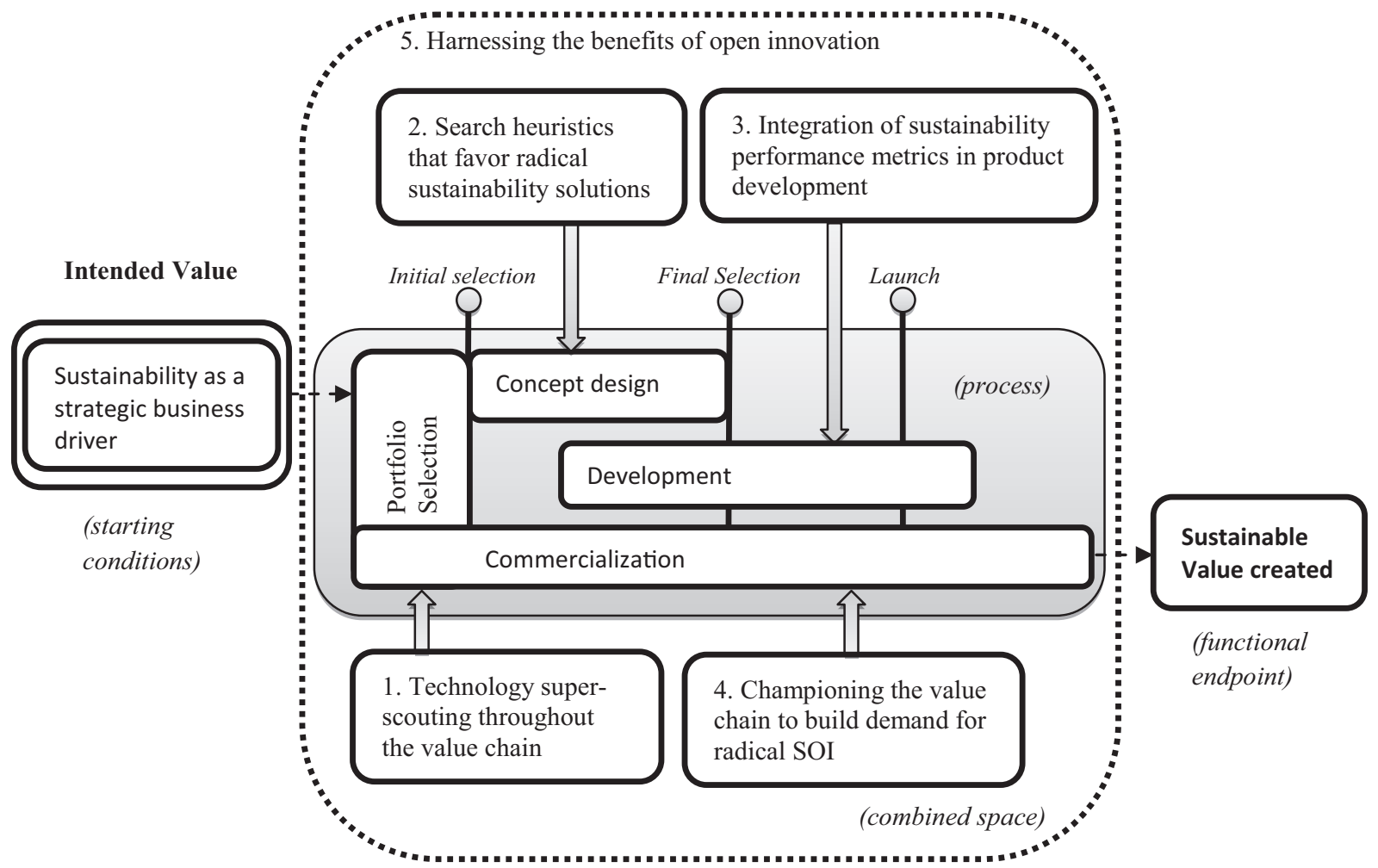

Figure 1. Critical organizational practices of the radical product SOI process influenced by firm strategic direction

We find that the starting conditions for Biosuccinium ${ }^{\mathrm{TM}}$ were located in the firm's strategy for using sustainability as a long-term business driver. DSM's strategic dialogue process - kicked off by the CEO - first identified long term societal challenges and then assessed the business opportunities for DSM - "where can we win?" This strategic approach provided a fertile ground for the technology super-scouting approach of the VP for Open Innovation, resulting in the new market-driven innovation unit of Bio-based Products and Services, one of DSM's Emerging Business Areas (EBAs). This triggered the start of the innovation process (represented in grey). Phases of innovation were found to be dynamic offering a flexible approach to 
product development (Iansiti and MacCormack, 1997) with key points of integration. For instance, commercialization began concurrent with portfolio selection enabling integration of early consumer feedback, while incremental and radical development streams were simultaneously pursued before the concept design was finalized. The functional endpoint of model was the successful commercialization of the radical product SOI which created sustainable value.

Figure 1 presents five critical organizational practices at various stages of the radical innovation process, spanning both the internal and external environment due to the extensive practice of open innovation. These organizational practices overlapped chronologically and had influence upon one another; thus, they must be seen as loosely-coupled rather than distinct and stand-alone practices. We discuss these in more detail below.

Firstly, the organizational practice of technology super-scouting helped DSM identify emerging business opportunities created by societal challenges, which could be accessed through radical innovation for systemic solutions. This practice helped DSM with its portfolio selection and commercialization processes by identifying which bio-based product(s) could have market potential and what value propositions may cause customers to switch from fossil-fuel derived incumbents. Secondly, search heuristics within the concept design phase were set to favor radical sustainability solutions. By backcasting from the ideal production route, both economically and environmentally, a novel way to make the product was found which offered a best-in-class environmental footprint. Thirdly, environmental sustainability measures were integrated into performance metrics of product development. This organizational practice, through the use of LCA, guided developmental decision-making to ensure the strategic aim of developing a sustainability advantaged product. Fourthly, the firm sought to act as a value chain 'captain' to build demand for bio-based succinic acid amongst brand manufacturers, and trigger a systemic change in the value chain. Here the firm's strong reputation in both radical innovation and sustainability helped organize market pull, as brand owners readily engaged with what was perceived to be a credible, long-term sustainability solution. Finally, the innovation process was driven by an open innovation approach. We also found that the firm's proactive sustainability strategy harnessed the benefits of open innovation as it facilitated engagements with like-minded external actors (e.g. industry experts, universities, brand owners) and formal innovation partners (e.g. Roquette Freres).

Similar to Keskin et al.'s (2013) study of radical product SOI within small entrepreneurial firms, we found that 'external validation', 'network', and 'market orientation' were critical organizational practices. Firstly, external validation was identified in our study as an early stage innovation activity. However, for DSM the purpose was to understand the market opportunity rather than attract investors, and was performed through the technology super scout rather than innovation competitions. Secondly, DSM made use of existing networks to garner expert industry opinions and ideas, and give some assistance in the development phase. Thirdly, Biosuccinium ${ }^{\mathrm{TM}}$ had a market orientation, partnering with direct customers to test and optimize the product, and jointly push the commercialization to intermediaries in the value chain. However, our model presents the radical innovation process in a multinational firm as more dynamic (Iansiti and MacCormack, 1997) and without an internal/ external distinction in organizational practices due to the ingrained practice of open innovation. In addition, our findings provide more insight into front end innovation and illustrate how the execution of these organizational practices was influenced by top-level corporate strategy. Furthermore, our study illustrates how radical SOI by a multinational company can result in systemic change along a value chain.

Previous studies have identified a number of ways in which corporate strategy may influence innovation activities including how they are organized within a firm, the selection of innovations within a portfolio, and formalized mechanisms through metrics screening product performance. Our study of Biosuccinium ${ }^{\mathrm{TM}}$ offers empirical support for these mechanisms. DSM organizationally separated its radical innovation activities into emerging business areas (Bower and Christensen, 1995), made use of explicit sustainability metrics in the development phase (Blomquist and Sandström, 2004), and ensured that selecting to pursue bio-based succinic acid met its strategic aims (Cooper et al., 2001). However, unlike previous studies we argue that corporate sustainability strategy also influenced the execution of other organizational practices within the innovation process. For instance, 'technology super-scouting' was performed with the specific intention of finding market opportunities for sustainability solutions and identifying how they may be successfully exploited. Search heuristics favored radical SOI by backcasting from the ideal sustainable product and then determining ways to produce it. The open innovation approach was facilitated by the firm's pre-existing reputation as a front-runner in sustainability.

Over the past decade, traditional innovation literature has emphasized the importance of going beyond the firm's organizational boundaries to help develop new products through open innovation (Chesbrough, 2003). Organizational sustainability scholars have identified the importance of collaboration for SOI due to its added complexity and uncertainty (Adams et al., 2015), and have begun to consider how the relationship between open innovation and sustainability is synergistic (Slotegraaf, 2012). Our case contributes to these discussions by providing empirical evidence on how a SOI process for a radical new product was enhanced by a company's strategy for open innovation involving internal and external parties (Ancona and Caldwell, 1992; Sivasubramaniam et al., 2012).

Our findings suggest that open innovation created a combined internal and external space for organizational practices, enabling an externally-oriented approach to their respective execution. This critically reduced the risk and uncertainty of radical product SOI in four key ways. Firstly, changes to the raw material (fossil-fuel) inputs for production were required (De Marchi, 2012). By forming a joint venture partnership with a supplier, DSM ensured access to the new raw material (biomass), but also improved product development and shared risk (Johnson, 2009). Secondly, the firm acquired valuable market knowledge through 'technology super-scouting', an innovative practice that gathered information on the size of the market opportunity and potential value propositions. Thirdly, the firm was able to source ideas (Ayuso et al., 2011) by engaging with industry experts interested in new bio-based products. For example, a discussion session was held to successfully solve the 
technological problem of creating a new sustainable production route (Halila and Rundquist, 2011). Finally, the firm practiced open innovation by working with external institutions to acquire scientific knowledge that reduced the complexity of developmental decision making, and again reduce business risk.

We believe these findings make interesting contributions to the open innovation literature by highlighting the importance of combining internal and external processes to create a complete knowledge chain towards successful innovation (Cohen and Levinthal, 1990). Furthermore, our findings highlight the importance of 'front-end' innovation (Van den Ende et al., 2015) within radical SOI.

\section{Front-end innovation}

Two key organizational practices within the front end of the innovation process were identified by our case findings. The first we label 'technology super-scouting', which we argue is a key application of the open innovation approach. In particular, technology super-scouting relied upon ideas from important value chain actors to inform DSM's radical SOI process, shaping how the product was developed. Through the process of technology super-scouting, DSM could strategically prioritize which bio-based products to take forward in the innovation process, and could also identify which sustainability dimensions were most valued by other value chain actors. This type of work was encouraged and guided by the firm's proactive corporate strategy on sustainability. This organizational practice allowed DSM to reduce the commercial risks of radical SOI and to reduce the ambiguity of trade-off decisions by gaining insights from downstream users (Foster et al., 2000).

Secondly, search heuristics at the concept design phase also allowed DSM to search for and choose a radical sustainability solution as opposed to an incremental solution. While the organizational literature has addressed search processes in innovation (Levinthal, 1997), empirical research is scarce (Ethiraj and Levinthal, 2004) and search processes have rarely been studied in the context of innovation directed at broader social goals, such as sustainability. The Biosuccinium ${ }^{\mathrm{TM}}$ case illustrates the important influence of a proactive corporate sustainability strategy on search processes for radical sustainability solutions. Because the company began the search processes with radical targets of the 'ideal' sustainable product, the innovation team was able to successfully backcast (Hallstedt et al., 2013) to find a novel production route.

\section{Implications for practice}

Our findings give insight into which organizational practices innovation managers could select for successful radical SOI. Our findings show how innovation managers may execute front-end innovation practices to orientate toward radical solutions, and look beyond using only formalized mechanisms for embedding organizational sustainability strategy into innovation activities. We also recommend that firms with a proactive sustainability strategy should consider adopting an open innovation approach, as the two seem synergistic. Our findings show that by offering credible sustainability solutions, new relationships may be formed, which can support changes through the entire value chain. Furthermore, our findings give an indication as to how innovation managers may approach sourcing ideas that pursue both market opportunity and positive societal impact. In particular, large firms may seek to appoint a technology-super scout to help build relationships and acquire market knowledge.

\section{Conclusions, limitations and future research}

Our paper is the first to provide an empirically grounded understanding of how a multinational firm's corporate strategy influences the outcome of radical innovation activities through a set of mechanisms encapsulated in Figure 1. Critically, by explicitly choosing sustainability as a strategic driver for new business, DSM was able to develop and launch a radical new biobased product that enabled a value chain shift away from petrochemicals. Specifically, our case study identifies five concurrent organizational processes: technology super-scouting throughout the value chain, search heuristics that favor radical sustainability solutions, integration of sustainability performance metrics in product development, championing the value chain to build demand for radical sustainability oriented product innovation, and harnessing the benefits of open innovation. We believe the processes identified in this paper help to open the 'black box' of radical SOI (Boons and Lüdeke-Freund, 2013). In particular, our findings emphasize the importance of corporate strategy and open innovation in radical SOI, and identify a number of organizational processes that facilitate this activity beyond portfolio management and life cycle assessment.

Our study has the following two main limitations. First, while the DSM case is a compelling example of radical SOI, it is a singular case study and thus we are unsure of the transferability of these results to other settings. Second, we relied principally on interviews with DSM/Reverdia employees, obtaining largely retrospective accounts. While we used triangulation and multiple source of evidence (Yin, 2003), we recognize that the study may not be completely free from bias, which may distort its findings.

Based on our case findings, we encourage future research to provide further insight into radical SOI and how corporate sustainability strategy may affect the process. In particular, we highlight a need to understand the differences between the organizational practices of SMEs (Hockerts and Wüstenhagen, 2010; Keskin et al., 2013) and multinational companies, and also further delineate what is effective for incremental and radical SOI (Dangelico, 2015). We invite studies to explore the extent and under what conditions our findings may be transferable. For instance, the organizational practice of 'technology super-scouting' is a potentially effective mechanism for any corporate strategy to influence the innovation process. Based on 
our findings the application of open innovation for sustainability outcomes appears to be a fruitful area for further inquiry. Studies may help understand the spectrum of types (Slotegraaf, 2012) and give further insight into the synergistic relationship. Finally, we believe there is much to be gained by investigating the critical front-end of the SOI process (Van den Ende et al., 2015), in particular the role of 'technology super-scouting' and search heuristics.

\section{Acknowledgements}

This study was made possible by a grant from the Dutch Ministry of Economic Affairs: Grant number IPCR1101. We thank the Ministry for their interest and support for this work. Our special thanks to the people from DSM/Reverdia for participating in this research and specifically to Feike Sijbesma (CEO), Marcel Wubbolts (Chief Technology Officer), Rob Kirschbaum (VP Open Innovation) and Will van den Tweel (General Manager, Reverdia) for their support. Finally we would like to express our gratitude to the three anonymous reviewers and the editors for their constructive suggestions and comments.

\section{Appendix}

Example interview protocol for semi-structured interview with DSM employee.

\section{(1) Personal Role}

- What is your personal background?

- What is your position at the company?

- Can you explain your role?

- At what stage did you begin to be involved in the innovation process?

(2) Overview of the history and events of the innovation process

- Can you give me the story of the Bio-based succinic acid innovation process?

- Can you explain the current status of the innovation?

- When did it all start?

- Where did the idea for the innovation come from?

- Why were you generating ideas in this area?

- Why was bio-based succinic acid selected to be developed?

- Can you tell me about the technology challenge session?

- How was the innovation developed?

- How did issues of sustainability affect the development phase?

(3) Internal and external factors influencing the process

- Can you explain what external and internal factors influenced the innovation process?

- What external and internal parties were involved in this innovation?

- Can you give me the story of the partnership with Roquette Freres?

- Can you tell me how the approach of open innovation was applied?

\section{(4) Reflections and closing}

- What were the major challenges to the innovation process?

- How were these challenges overcome?

- What were the major facilitators to the innovation process?

- What were the critical organizational practices for the success of the innovation?

- How would you summarize the effect of the corporate sustainability strategy on the innovation process?

- Is there anything else you like to discuss?

- Who else should I be speaking to?

\section{References}

Adams, R., Jeanrenaud, S., Bessant, J., Denyer, D., Overy, P., 2015. Sustainability-oriented innovation: a systematic review. International Journal of Management Reviews 18 (2), 180-205 early viewing.

Ancona, D.G., Caldwell, D.F., 1992. Bridging the boundary: external activity and performance in organizational teams. Administrative Science Quarterly 37 (4), 634-651.

Arnold, M.G., Hockerts, K., 2011. The greening Dutchman: Philips' process of green flagging to drive sustainable innovations. Business Strategy and the Environment 20 (6), 394-407.

Ayuso, S., Rodríguez, M.A., García-Castro, R., Ariño, M.A., 2011. Does stakeholder engagement promote sustainable innovation orientation? Industrial Management \& Data Systems 111 (9), 1399-1417.

Bansal, P., Hoffman, A. (Eds.), 2012. The Oxford Handbook of Business and the Natural Environment. Oxford University Press, Oxford.

Blomquist, T., Sandström, J., 2004. From issues to checkpoints and back: managing green issues in R\&D. Business Strategy and the Environment 13 (6), 363-373. 
Boons, F., Lüdeke-Freund, F., 2013. Business models for sustainable innovation: state-of-the-art and steps towards a research agenda. Journal of Cleaner Production 45, 9-19.

Bower, J.L., Christensen, C.M., 1995. Disruptive technologies: catching the wave. Harvard Business Review 73 (1), 43-53.

Carrillo-Hermosilla, J., del Rio, P., Könnöla, T., 2010. Diversity of eco-innovations: reflections from selected case studies. Journal of Cleaner Production 18 (10-11), 1073-1083.

Chen, G.Q., Patel, M.K., 2012. Plastics derived from biological sources: present and future: a technical and environmental review. Chemical Reviews 112 (4), 2082-2099.

Chesbrough, H., 2003. Open innovation: The New Imperative for Creating and Profiting from Technology. Harvard Business School Press, Cambridge, MA. Cohen, W.M., Levinthal, D.A., 1990. Absorptive capacity: a new perspective on learning and innovation. Administrative Science Quarterly 35 (1), 128-152.

Cok, B., Tsiropoulos, I., Roes, A.L., Patel, M.K., 2014. Succinic acid production derived from carbohydrates: an energy and greenhouse gas assessment of a platform chemical toward a bio-based economy. Biofuels, Bioproducts and Biorefining 8 (1), 16-29.

Cooper, R.G., Edgett, S.J., Kleinschmidt, E.J., 2001. Portfolio Management for New Products, second ed. Perseus Books, Cambridge, MA.

Corley, K.G., Gioia, D.A., 2004. Identity ambiguity and change in the wake of a corporate spin-off. Administrative Science Quarterly 49 (2), 173-208.

Dangelico, R., Pujari, D., 2010. Mainstreaming green product innovation: why and how companies integrate environmental sustainability. Journal of Business Ethics 95 (3), 471-486.

Dangelico, R., Pontrandolfo, P., Pujari, D., 2013. Developing sustainable new products in the textile and upholstered furniture industries: role of external integrative capabilities. Journal of Product Innovation Management 30 (4), 642-658.

Dangelico, R.M., 2015. Green product innovation: where we are and where we are going. Business Strategy and the Environment. http://dx.doi.org/10.1002/ bse.1886. Early viewing.

De Marchi, V., 2012. Environmental innovation and R\&D cooperation: empirical evidence from Spanish manufacturing firms. Research Policy 41 (3), $614-623$.

De Medeiros, J.F., Ribeiro, J.L.D., Cortimiglia, M.N., 2014. Success factors for environmentally sustainable product innovation: a systematic literature review. Journal of Cleaner Production 65, 76-86.

Dewar, R.D., Dutton, J.E., 1986. The adoption of radical and incremental innovations: an empirical analysis. Management Science 32 (11), 1422-1433.

Driessen, P., Hillebrand, B., Kok, R., Verhallen, T., 2013. Green new product development: the pivotal role of product greenness. IEEE Transactions on Engineering Management / Professional Technical Group on engineering Management 60 (2), 315-326.

DSM, 2010. DSM in motion: driving focused growth. Presentation by Feike Sijbesma, CEO. DSM Capital Markets Days 2010.

DSM, 2011. DSM Integrated Annual Report. DSM, Netherlands.

DSM, 2011. DSM Bio-Based Products \& Services: Creating Sustainable Solutions for a New Bio-Industrial Era. DSM, Netherlands.

DSM, 2012. Low pH Fermentation to Succinic Acid, the Basis for Efficient Recovery. Presentation by Mickel Jansen at Bio4Bio Conference, Copenhagen, Feb 29 th 2012.

Eisenhardt, K., 1989. Building theories from case research. Academy of Management Review 14 (4), $532-550$.

Ethiraj, S.K., Levinthal, D., 2004. Modularity and innovation in complex systems. Management Science 50 (2), $159-173$.

Foster Jr., S.T., Sampson, S.E., Dunn, S.C., 2000. The impact of customer contact on environmental initiatives for service firms. International Journal of Operations \& Production Management 20 (2), 187-203.

Geels, F.W., Hekkert, M.P., Jacobsson, S., 2008. The dynamics of sustainable innovation journeys. Technology Analysis \& Strategic Management 20 (5), $521-536$.

Green, S.G., Welsh, M.A., 2003. Advocacy, performance, and threshold influences on decisions to terminate new product development. Academy of Management Journal 46 (4), 419-434.

Halila, F., Rundquist, J., 2011. The development and market success of eco- innovations: a comparative study of eco-innovations in Sweden. European Journal of Innovation Management 14 (3), 278-302.

Hall, J., 2002. Sustainable development innovation; a research agenda for the next 10 years. Editorial for the 10 th anniversary of the Journal of Cleaner Production. Journal of Cleaner Production 10 (3), 195-196.

Hall, J., Vredenburg, H., 2003. The challenges of innovating for sustainable development. MIT Sloan Management Review 45 (1), $61-68$.

Hall, J., Wagner, M., 2012. Integrating sustainability into firms' processes: performance effects and the moderating role of business models and innovation. Business Strategy and the Environment 21 (3), 183-196.

Hallstedt, S., Thompson, A., Lindahl, P., 2013. Key elements for implementing a strategic sustainability perspective in the product innovation process. Journal of Cleaner Production 51, 277-288.

Hansen, E.G., Große-Dunker, F., 2013. Sustainability-oriented innovation. In: Idowu, S.O., Capaldi, N., Zu, L., Das Gupta, A. (Eds.), Encyclopaedia of Corporate Social Responsibility, vol. I. Heidelberg, Germany \& Springer, New York, pp. 2407-2417.

Hart, S., Milstein, M., 2003. Creating sustainable value. Academy of Management Executive 17 (2), 56-67.

Henard, D.H., Szymanski, D.M., 2001. Why some new products are more successful than others. Journal of Marketing Research 38 (3), $362-375$.

Hockerts, K., Wüstenhagen, R., 2010. Greening Goliaths versus emerging Davids - theorizing about the role of incumbents and new entrants in sustainable entrepreneurship. Journal of Business Venturing 25 (5), 481-492.

Horbach, J., Rammer, C., Rennings, K., 2012. Determinants of eco-innovations by type of environmental impact e the role of regulatory push/pull, technology push and market pull. Ecological Economics 78, 112-122.

Humble, J., Jones, G., 1989. Creating a climate for innovation. Long Range Planning 22 (4), 46-51.

Iansiti, M., MacCormack, A., 1997. Developing products on Internet time. Harvard Business Review 75 (5), $108-117$.

Ilinitch, A.Y., Schaltegger, S.C., 1995. Developing a green business portfolio. Long Range Planning 28 (2), $29-38$.

Johnson, T.E., 2009. Supplier involvement in new product development and innovation: taking stock and looking into the future. Journal of Purchasing \& Supply Management 15 (3), 187-197.

Keskin, D., Diehl, J., Molenaar, N., 2013. Innovation process of new ventures driven by sustainability. Journal of Cleaner Production 46, 50-60.

Klewitz, J., Hansen, E.G., 2014. Sustainability-oriented innovation of SMEs: a systematic review. Journal of Cleaner Production 65, 57-75.

Kolk, A., Mauser, A., 2002. The evolution of environmental management: from stage models to performance evaluation. Business Strategy and the Environment $11(1), 14-31$.

Levinthal, D., 1997. Adaptation on rugged landscapes. Management Science 43 (7), 934-950.

Lincoln, Y.S., Guba, E.G., 1985. Naturalistic Inquiry, vol. 75. Sage, Beverly Hills, CA.

Lofland, J., Snow, D., Anderson, L., Lofland, L.H., 2006. Analyzing Social Settings. Wadsworth Publishing Company, Belmont, CA.

Miles, M.B., Huberman, A.M., 1994. Qualitative Data Analysis: An Expanded Sourcebook. Sage.

Nidumolu, R., Prahalad, C., Rangaswami, M., 2009. Why sustainability is now the key driver of innovation. Harvard Business Review 87 (9), 57-64.

O'Connor, G.C., DeMartino, R., 2006. Organizing for radical innovation: an exploratory study of the structural aspects of Ri management systems in large established firms. Journal of Product Innovation Management 23 (6), 475-497.

Patel, M., Crank, M., Dornburg, V., Hermann, B., Roes, L., Hysing, B., et al., 2006. Medium and long-term opportunities and risks of the biotechnological production of bulk chemicals from renewable resources. The BREW Project. Prepared under the European Commission's GROWTH Programme (DG Research), Utrecht University, Utrecht; Available from: https://www.researchgate.net/profile/Leonard_Overbeek/publication/27704442_Medium_and_ Long-Term_Opportunities_and_Risks_of_the_Biotechnological_Production_of_Bulk_Chemicals_from_Renewable_ResourcesThe_BREW_Project/links/ 00b7d518267ef15088000000.pdf.

Plowman, D., Baker, L., Beck, T., Kulkarni, M., Solansky, S., Travis, D., 2007. Radical change accidentally: the emergence and amplification of small change. Academy of Management Journal 50 (3), 515-543. 
Porter, M., van der Linde, C., 1995. Green and competitive: ending the stalemate. Harvard Business Review 73 (5), $120-134$.

Sandberg, B., Aarikka-Stenroos, L., 2014. What makes it so difficult? A systematic review on barriers to radical innovation. Industrial Marketing Management 43 (8), 1293-1305.

Schaltegger, S., Hansen, E., Lüdeke-Freund, F., 2016. Business models for sustainability. A co-evolutionary analysis of sustainable entrepreneurship, innovation and transformation. Organization \& Environment 12 (1), 1-26.

Schumpeter, J.A., 1934. The Theory of Economic Development. Harvard University Press, Cambridge, MA.

Schwartz, M., Schwartz, C., 1955. Problems in participant observation. American Journal of Sociology 60 (4), $343-353$.

Sivasubramaniam, J., Liebowitz, S.J., Lackman, C.L., 2012. Determinants of new product development team performance: a meta-analytic review. Journal of Product Innovation Management 29 (5), 803-820.

Slater, S.F., Mohr, J.J., Sengupta, S., 2014. Radical product innovation capability: literature review, synthesis, and illustrative research propositions. Journal of Product Innovation Management 31 (3), 552-566.

Slotegraaf, R.J., 2012. Keep the door open: innovating toward a more sustainable future. Journal of Product Innovation Management 29 (3), 349-351.

Steffen, J., 2011. Feike Sijbesma: a vision of life. Sight and Life 25 (2), 58-60.

The Worldwatch Institute, 2015. Vital Signs. In: The Trends That Are Shaping Our Future, vol. 22. Island Press, Washington, USA.

Tukker, A., Butter, M., 2007. Governance of sustainable transitions: about the 4(0) ways to change the world. Journal of Cleaner Production 15 (1), $94-103$.

UNWCED - United Nations World Commission on Environment and Development, 1987. Our Common Future. Oxford University Press, New York.

Van den Ende, J., Frederiksen, L., Prencipe, A., 2015. The front end of innovation: organizing search for ideas. Journal of Product Innovation Management 32 (4), 482-487.

Wagner, M., 2007. Integration of environmental management with other managerial functions of the firm: empirical effects on drivers of economic performance. Long Range Planning 40 (6), 611-628.

Whiteman, G., Walker, B., Perego, P., 2013. Planetary boundaries: ecological foundations for corporate sustainability. Journal of Management Studies 50 (2), 307-336.

Wu, Z., Pagell, M., 2011. Balancing priorities: decision-making in sustainable supply chain management. Journal of Operations Management 29 (6), $577-590$.

Yin, R.K., 2003. Case study Research: Design and Methods, third ed. Sage Publications, Thousand Oaks.

\section{Biographies}

Steve Kennedy is an Assistant Professor at Rotterdam School of Management, Erasmus University. His work focuses on how corporate sustainability strategies are translated into successful innovation and the formation of future-ready sustainable business models. His doctoral thesis on the challenges of operationalizing sustainability at the local level was highly commended at the Emerald/EFMD Outstanding Doctoral Research Awards 2010. He currently teaches courses in corporate sustainability and climate change strategy. Email: skennedy@rsm.nl

Gail Whiteman is Professor of Sustainability and Climate Change at Lancaster University where she is the Director of the Pentland Centre for Sustainability in Business. She is also the Professor-in-Residence at the World Business Council for Sustainable Development (WBCSD). In 2011, Professor Whiteman was a Global Finalist in the Aspen Institute's high-profile ranking of Faculty Pioneers in sustainability. She is widely published in top management and ecology journals including the Academy of Management Journal, Journal of Management Studies, Nature, Organization Studies, Business Strategy and the Environment, Journal of Management Inquiry and Journal of Business Ethics. Email: g.whiteman@lancaster.ac.uk

Jan van den Ende is Professor of Technology and Innovation at Rotterdam School of Management, Erasmus University and holds the International Chair of Management, LUISS Universita Guido Carli, Rome, Italy. His research interests include firm-internal and -external idea management, control of new product development projects, design management and sustainability oriented innovation. Professor van den Ende has published in numerous journals including Journal of Management Studies, Organization Studies, Harvard Business Review, Journal of Product Innovation Management, Research Policy, and IEEE Transactions on Engineering Management. Email: jende@rsm.nl 